\title{
The Role of Malcolm X's Speeches in Solidifying his Autobiography
}

\author{
Ammar Aqeeli \\ American Literature, Jazan University, Saudi Arabia \\ Email: ammar383@live.com
}

\begin{abstract}
This paper demonstrates how a literary text can be approached through a linguistic framework to enhance one's reading and interpretation of it. It aims at examining the power of The Autobiography of Malcolm X: As Told to Alex Haley by analyzing the narrator's description of his early speeches. I draw upon the appraisal framework, and I focus on Malcolm's utilization of affect, judgment, and appreciation in a number of his speeches that he reported in the book. In those speeches, Malcolm adopts resources from the appraisal framework to align his audience with his position. His performance of affective stance to construct the entire problem of race in America contributed to the success of his book for more than 50 years since its publication.
\end{abstract}

Keywords: Appraisal; Black Power; Civil Rights; Malcolm X; Racism

\section{INTRODUCTION}

Malcolm X, originally named Malcolm Little, was born on 19 May 1925 in Omaha, Nebraska. He changed his last name to X, which signifies an unknown, as an act of rejection of his "slave" name. Malcolm was an influential African-American civil rights leader and a prominent figure in the Nation of Islam (NOI) (which was founded in Detroit, Michigan, United States in 1930 by Wallace D. Fard Muhammad. It is a black nationalist organization whose goal was to uplift and liberate black people in America). Its leaders rejected integration and preached black supremacy and racial separation. His father, Earl Little, a Baptist minister and a member of Marcus Garvey's Universal Negro Improvement Association, was arguably killed by a streetcar when Malcolm was only six years old. However, Malcolm strongly believed that his father had been murdered by the Black Legion who placed his body on the trolley tracks to make it look like an accident. Coming from a very poor family, Malcolm became involved in criminal activities such as robbery, drug dealing, and hustling on streets, which sent him to jail for six years. However, his time in prison led him to a complete change and a positive perception of his race through the teachings of Elijah Muhammad (who was the leader of the Nation of Islam from 1934 until his death in 1975).

A number of critics have questioned the accuracy of Malcom's vivid account of his life story in his autobiography. Manning Marble (2011) asserted that Malcolm's narration of his invol- vement in criminal activities during his younger years is exaggerated. The aim of this study is not to reassess this claim but to examine Malcom's adoption of linguistic strategies as an effective way to give his book an ongoing appeal to a wide African American reading public. As is the case with most autobiographies, The Autobiography of Malcolm X contains fictional elements, commonly "self-invention," which is a successful strategy for him "to reach the most marginalized sectors of the black community" and to give "justification to their hopes" (Marable 2011, Prologue, Life Beyond the Legend). Within Malcolm's goal of bringing hope to the disenfranchised black population, is what is described as actual excerpts from his speeches, whose accuracy could also be called into question. However, whether these speeches were accurately reported or not, they were incorporated into the book to reflect Malcolm's desire to free the black minds from the effects of the inferiority complex largely imposed by the oppressor. I argue that Malcom's employment of some linguistic elements was to show how his speeches work well to mesmerize his readers and get his message of black liberation across to them.

At the core of The Autobiography of Malcolm $X$ is a discourse of conversion that Malcolm wanted to share with his readers. The goal of his work, so as is with many works of literature by African American writers, is to indict racism and its psychological consequences for black people. In the book, Malcolm's condemnation of white racism in mainstream America comes through narrating his religious conversion. $\mathrm{He}$ portrayed his renouncement of Christianity and 
his conversion to the Black Muslim teachings as the first right step to help African Americans in their struggle with anti-black racism: "The Holy Bible in the white man's hands and his interpretations of it have been the greatest single ideological weapon for enslaving millions of nonwhite human beings" (X \& Haley 1992, 277). For Malcolm, Christianity, as interpreted by the oppressor, will not bring justice to people of color in America. He emphasizes the importance of his religious conversion as it mitigates the negative consequences of oppression manifest in the psyche of African Americans. Malcolm speeches that describe his conversion and urge his audiences to join the Nation of Islam work as models of "psychological changes," through which their dignity and worth are affirmed (Franklin 19989, 296).

In the book, Malcolm (1992) describes his first contact with Mr. Muhammad. He proclaims that he used to love being around the whites in prison before his exposure to Mr. Muhammad's message. He believes that Mr. Muhammad's teachings influenced him and changed his attitude toward his black "brothers." Mr. Muhammad stressed the importance of blacks not to buy into the idea that they are "inferior." His rhetoric emphasized the glorious pre-slavery history of black people as a strategy to destroy the negative images their oppressor constructed about them. As a result, Malcolm X informs his readers that he decides to devote much of his time searching for more details about black history. He spends most of his time reading books about black people's history. He reads Wonders of the World, which contains pictures of archeological finds and statues depicting non-European people. He also reads Carter G. Woodson's Negro History, which opens his "eyes about black empires before black slave was brought to the United States" (p. 178). Malcolm (1992) states that Mr. Muhammad taught him about the forgotten civilizations of black people, such as Coptic Christian Empires, Ethiopia, "the earth's oldest continuous black civilization" (p. 178). He demonstrates that he got attached to the belief that the black man was the "Original Man" after he read Gregor Mendel's Findings in Genetics. Malcolm declares that his life in prison gave him the desire to open the eyes of his "brainwashed black brethren to some truths about the black race" (p. 185).

The goal of this study is to examine how Malcolm's early speeches in his bestselling The Autobiography of Malcolm $X$ have contributed to popularizing his book for more than 50 years since its publication. Malcolm's description of his life before and after his embrace of the NOI's teachings takes up three-fourths of the book. In so doing, Malcolm wanted to emphasize the transformative power of the NOI's message and its potential to expose the historical and contemporary devaluations of the humanity of black people. The power of Malcolm's narrative lies in his early speeches that he claims he delivered while he was a minister in the Nation of Islam. These speeches are intended to dismantle the combined "interrelationship" between the oppressor's linguistic forms and "the surrounding semiotic media to express macro-level messages of power, control, racism, hegemony, dominance and discrimination" (Strauss \& Feiz, 20013, p. 316). Indeed, at the center of these speeches is the notion of raising black consciousness that racial integration inhibits black self-determination. For Malcolm, integration makes black people dependent on the white man, which perpetuates the idea that he is superior over them. For almost one century since the abolition of slavery, African Americans kept seeking recognition of their humanity from their oppressor, but they are not even allowed to formulate a positive self-defined black identity.

The result was that black people in America were trapped by "double consciousness," a "sense of always looking at one's self through the eyes of others" (Du Bois, 1994, p. 2). Malcolm's message in his early speeches call for awakening black people racial consciousness and for transforming their distorted reality. The effectiveness of these speeches can be attributed to the fact that they express the words that are on the minds and in the hearts of thousands of oppressed African Americans. Moreover, Malcolm's reliance on a variety of linguistic resources maintains the strong relationship that he develops with his audiences throughout the book.

\section{METHODOLOGY}

The data selected for this study are samples from Malcolm X's speeches during his early years as a minister in the Nation of Islam. These speeches are very important in achieving his goal of opening "the eyes of his brainwashed black brethren to some truths about the black race" (X \& Haley, 1992, p. 185). However, his success in increasing the number his followers was not easy. For instance, Malcolm reports that each time he invited black people to Mr. Muhammad's teachings, they "rebuffed and even ridiculed" him (p. 205). Malcolm knows that "the Nation of Islam's strict moral code and discipline was what repelled them" (p. 225). Despite all this, and after several 
speeches, Malcolm (1992) claims that his followers increased from only 400 members to around 40,000 members from 1952 to 1960 , (p. 417). In addition, Malcolm expresses his excitement about the fact that millions of people worldwide were listening to his speeches and interviews on radio and television (p. 205). The ideas derived from these speeches address the realities of everyday black people, and they demand to affect socio-economic change through which the condition of black people in America can be improved

The interpersonal function of language derived from M.A.K. Halliday's (2015) systematic functional linguistics (SFL) suggests that speakers use language as a means of their own intrusion into the communication events. They set up relationships between themselves and the audiences through expressing their attitudes, evaluations and comments. They express their own attitudes and judgments and seek to influence the attitudes and behavior of others. According to M. A. K. Halliday (2015), "the speaker adopts for himself a particular speech role, and in so doing assigns to the listener a complementary role which he wishes him to adopt in his turn." (p. 246). Speakers play an important communicative role through language to maintain social relations. The interpersonal function of language is important to establish and maintain all human relationships. Through language, social groups and individuals are identified, integrated and reinforced. Generally speaking, the interpersonal function of language is concerned with the way humans bring themselves into being through language.

Inside the interpersonal function of language, the appraisal framework demonstrates the ways speakers/writers identify themselves with other individuals in their society or other social groups. According to Martin (2000), appraisal refers to "the semantic resources used to negotiate emotions, judgment and evaluations, alongside resources for amplifying and engaging with these evaluations" (p. 145). The appraisal framework focuses on the social function of language conveyed in the communication events, through which speaker/writer "engage with sociallydetermined value positions and thereby align or dis-align themselves with the social subjects who hold to these positions" (White, 2011, p. 14). They also take stance and express emotions and feelings to influence the reaction of their potential respondents and construct an ideal audience for their discourses. According to Martin and White (2005), the appraisal framework is centered upon the concept of stance (p. 40), which largely depends on Michael Stubbs' (1986) argument that "whenever speakers (or writers) say anything, they encode their point of view towards it" (p. 1).

I rely on the appraisal framework and focus on Malcolm's affect, judgment, and appreciation, which are reflected in his speeches during his activities as a civil rights leader. Martin and White (2005) proposed three resources for the appraisal framework: attitude, engagement, and graduation. Attitude, which is divided into affect, judgment, and appreciation, refers to "our feelings, including emotional reactions, judgments of behavior and evaluation of things" ( $p$. 35). Technically, affect refers to the resources for expressing emotional states, judgment is the "resources for judging character," and appreciation is the "resources for valuing the worth of things" (p. 35). These resources can be classified into inscribed or invoked evaluations. Inscribed resources state the ideological position of the speaker explicitly. For example, Malcolm calls white man "devilish." In doing so, he explicitly asks the audience to share this evaluation. The invoked evaluations draw the audience towards the speaker's position, which is explicitly expressed by the inscribed attitude. Since stance is an interpersonal experience, affective stance in Malcolm speeches reveals different levels of positive and negative emotional involvement such as sympathy, hate, sadness, and anger.

Moreover, attitudes "can be more or less intense, that is they may be more or less amplified" (Martin \& Rose, 2003, p. 23). In other words, they are gradable in that "their volume can be turned up and down depending on how intensely we feel" (p. 23). The resources that the speakers use to display the degree of their reactions' strength are called amplification. Also, the attitude can be attributed to the speaker or it may be attributed to some other source. In other words, who else does make attitudes besides the speaker? One very common way to make evaluative attitudes is "to create another voice in the story, by using direct or indirect speech" (p. 23). In addition, people express their feelings in two different ways. They can express good feelings or bad feelings, which Martin and Rose (2003) called negative and positive affect. Moreover, affect can be expressed directly, or it can be inferred indirectly from the way people behave. These expressions of feelings are labeled as indirect or implied affect.

\section{RESULTS AND DISCUSSION}

Qualitative analysis of Malcolm speeches examines how affective stance constructs or fra- 
mes the entire problem of race in America. It also examines how the whites as the enemy are generally represented and how the blacks as the victims are represented. In his efforts to draw his audience to question the humane and moral images that the white man constructed about himself, Malcolm reminds them of the traumatic episodes of slavery and its effects on their ancestors. In this way, Malcolm is trying to evoke an emotional reaction from his listeners, which is standing up with him against the systematic injustice against black people. In his speech in 1953 in Detroit Temple Number One, Malcolm (1992) asks his audience to "think of that black slave man filled with fear and dread, hearing the screams of his wife, his mother, his daughter being taken - in the barn ... being raped" (p. 206). Within this speech, Malcolm provides negative evaluations of the activities of white slaveholders.

Indeed, since affect is regarded as an emotional reaction to phenomena like slavery, it is normal that Malcolm constructs the activities of slaveholders with negative emotions. In their representations, Malcolm explicitly states that the actions of white slave masters make them controlling, "rapist," emasculating and threatening. These evaluations clearly express negative affect in that they express anger, fear, sadness, and disapproval. In the same speech in Detroit Temple, Malcolm says: "This white man always has controlled us ... [that] rapist slavemaster who emasculated the black man ... with threats, with fear ... until even today the black man lives with fear of the white man in his heart" (pp. 205-06). These negative evaluations are examples of inscribed attitudes and are employed to explicitly express Malcolm's judgment, which also has the invoked attitude potential to secure the audience's judgment to align with the speaker's position.

Malcolm's narration of some of the horrific episodes of slavery to his black audience functions as a tactic to involve them in their ancestors' feelings. He displays sympathy and empathy to those who were exploited by the institution of slavery, the most oppressive legal structure in American history. Malcolm (1992) expresses the slaves' emotions as follows:

Think of the black slave man filled with fear and dread, hearing the screams of his wife, his mother, his daughter being taken - in the barn, the kitchen, in the bushes! Think of it, my dear brothers and sisters! Think of hearing wives, mothers, daughters, being raped! And you were too filled with fear of the rapist to do anything about it! And his vicious, animal attacks' offspring, this white man named things like "mulatto" and "quadroon" and "octoroon" and all those things that he has called us - you and me - when he is not calling us "nigger"! (p. 206)

What Malcolm narrates about the oppression of slaves is very tragic. Therefore, most of the feelings are negative as one would not like to feel fear and dread or want to be anguished watching one family member being raped and doing nothing about it. Malcolm also employs direct expressions of feelings. He uses words that name specific emotions to directly describe a mental state such as "fear" and "dread." He also refers to the slaves' emotions physically, describing behaviors that also directly express emotion. For example, "hearing wives ... being raped" and "hearing [their] screams," describe a dreadful experience that involves an agonizing mental pain and emotional torment of the victims. According to Malcolm, both the slaves and their family members were experiencing physical and mental torment simultaneously.

Moreover, Malcolm (1992) creates another voice in the same speech to attribute feelings by using direct speech. He quotes terms that whites coined and used to judge blacks negatively. These words are "mulatto," "quadroon" and "octoroon." This intermediate source of judgment in Malcolm's speech is important in that it stirs his audience's emotions to condemn their oppressor. Indeed, these quoted terms are derogatory and came into use during slavery and used by whites to classify children of black and white parents. For instance, "mulatto" is a term comes from a Spanish word for mule, which is a cross between a horse and a donkey, a very ugly comparison. In other words, mixed-race were considered inferior and "vicious offspring." They were offspring of illegitimate non-consensual relationships, yet they had to endure white scorn. These terms like "mulatto" are evaluative judgments of a character but at the same time they evoke negative emotions such as anger and disapproval.

Same as affect, according to Martin and Rose (2003), "judgments of people's character can be positive or negative, and they may be judged explicitly or implicitly" (p. 28). Martin and Rose divided judgment into two types: personal judgments, which refer to the judgments of admiration and criticism, and moral judgments, which refer to the judgments of praise and condemnation. In Malcolm early speeches, he expresses both personal and moral judgments in different ways to represent differences between the black and white people. These representations serve to raise awareness among his black audience of how important that they need to realize the value of 
their race and themselves if they want respect and prosperity. These are basic rights that Malcolm (1992) believed the white man would not allow his people to have unless they separate themselves entirely from whites. According to Malcolm's speech in Detroit Temple One in 1953:

We did't land on Plymouth Rock, my brothers and sisters - Plymouth Rock landed on us! ... Give all you can to help Messenger Elijah Muhammad's independence program for the black man! ... This white man always has controlled us black people by keeping us running to him begging. 'Please, lawdy, please, Mr. White Man, boss, would you push me off another crumb down from your table that's sagging with riches ...' (p. 205)

In the speech above, Malcolm uses metaphor to construct implied criticism of white European pilgrims. According to David K. Clark and Robert V. Rakestraw (2008), the pilgrims found America for "white, Anglo-Saxon Protestants- WASP." In other words, non-WASPs were not welcomed and they "[came] on WASP terms, with WASP permission, and must adapt to WASP culture" (p. 264). According to Clark and Rakestraw (2008), the reason Malcolm said, "We did't land on Plymouth Rock, my brothers and sisters - Plymouth Rock landed on us," was because Africans were identified by their skins and "faced obstacles at every turn" (p. 264). Indeed, the African slaves were brought to the New World by force and against their will. Yet, this white, Anglo-Saxon Protestant kept increasing oppression and discrimination each time the black man desired liberation. Therefore, instead of the Africans landed on Plymouth Rock, which is a symbol of America, by their will and warmly welcomed and treated with dignity, the Plymouth Rock metaphorically landed on them, thus crushing their hopes and dreams for any prosperous future.

Moreover, there is an implied moral judgment of condemnation in Malcolm's use of Plymouth Rock's metaphor. According to Martin and Rose (2003), metaphor plays a role in constructing emotions (p. 27). In fact, these emotions, which come in the form of implied condemnation, express Malcolm's feelings of disappointment, hurt, anger and sadness. Malcolm's metaphor implies a moral condemnation of Christians who justified slavery as a moral necessity despite the fact that slavery was contrary to Christian practice. Instead of defending those who were unjustly brought to America, many Christians believed that they had a religious duty to convert slaves to Christianity as a way of furt- hering God's kingdom. According to John B. Boles (1998), "[one] justification for slavery was that it was a providentially designed institution Christianizing and civilizing the "heathen" of Africa" (p. 37). Malcolm also seems to condemn Christian denominations in America for not being quick in condemning slavery, which implies a covert endorsement of the practice. According to Junius P. Rodriguez (2007), "Among the Protestant religious communities in the United States, slavery did not emerge as a key moral concern until the 1850s" (p. 115). Malcolm's (1992) condemnation of the white slave master is clearly manifested in an earlier speech at Temple One in Detroit:

This is white man's Christian religion used to brainwash us black people! We have accepted it! We have embraced it! We have believed it! We have practiced it! And while we are doing all of that, for himself, this blue-eyed devil has twisted his Christianity, to keep his foot on our backs... to keep our eyes fixed on the pie in the sky and heaven in the hereafter... while he enjoys his heaven right here... on this earth... in this life. (p. 205)

In the speech above, Malcolm expresses negative moral judgments by condemning the morals of the white Christian. He condemns him as a liar who "twisted his Christianity" and as a "devil" who endorsed the plight of black slaves.

In the same speech that has "Plymouth Rock" metaphor, Malcolm (1992) indirectly criticizes his audience, implying the necessity of separation. He is not directly blaming the blacks. Instead, he is condemning white America for the racial status quo. Such a speech tactic serves to represent whites as the enemy and blacks as the victims. At the same time, it urges his audience to stop running to the white man, "begging. 'Please, lawdy, please, Mr. White Man, boss, would you push me off another crumb down from your table that's sagging with riches ..."' (p. 205). Malcolm hopes his people wake up and join his separatist movement if they want respect and prosperity. Although the white man has been controlling black people, Malcolm seems to imply that his people also share the criticism if they still have faith in this white man and his religion after all he had done to them. Therefore, according to Malcolm, his black audience has no excuse to stay brainwashed and at the mercy of white man.

Malcolm (1992) also expresses positive judgments to his audience. In the same speech in Temple One in 1953, he calls his audience, "my beautiful, black brothers and sisters" (p. 205). Malcolm explicitly expresses his admiration for the beauty of his people. He also judges them as 
"brothers and sisters," which signifies the closeness, unity, and strength they should adhere to and maintain like biological siblings. The word "beautiful" can also be utilized as a positive appreciation of their race and color. Although there are no superior races, Malcolm sends an explicit message to his small congregation to value the beauty and "superiority" of the black race. Malcolm's attitudes had the potential to affect those among his audience who had been frustrated by the white man's methods of control and oppression.

One of the speech tactics that Malcolm adopted in his early speeches was his awareness to speak "in terms that the people could understand." In June 1954 in Temple Seven in New York, Malcolm (1992) noticed the "heavy preponderance" of attendees were Christian women. Therefore, he decided "to offer something special for them" (p. 225). Malcolm speaks:

Beautiful black woman! The Honorable Elijah Muhammad teaches us that the black man is going around saying he wants respect; well, the black man never will get anybody's respect until he first learns to respect his own women! The black man... needs to shelter and protect and respect his black women. (p. 225)

Malcolm tailored his speech to show the female attendees how important they were in $\mathrm{Mr}$. Muhammad's teachings. When most of the attendees were males, Malcolm judged them positively and admired them as "beautiful" brothers. However, when the majority of the attendees were women, Malcolm admired them as "beautiful black woman." At the same time, he criticized the black men as disrespectful to their women. In this speech, Malcolm utilized positive and negative evaluative judgments to align with the black female attendees who were mistreated by their men, hoping that they would also align with his ideological position.

\section{CONCLUSION}

In this study, the appraisal framework demonstrates the social function of language conveyed in Malcolm's early speeches, to secure his audience's position in alignment with his own. It concludes that Malcolm takes stance and expresses emotions and feelings to influence the reaction of his potential respondents and to construct an ideal audience for his discourse. Malcolm's early speeches during his career as a minister in the Nation of Islam prove his good persuasive skills. Trough analyzing the stance-making elements in Malcolm's speeches in the Autobiography, it be- comes clear that the book intends to be read and reflected upon by African Americans of different generations. The linguistic forms applied in these speeches contribute to giving Malcolm's book an ageless appeal and value among his audiences. In fact, the narrator in the book brags about how these speeches were appealing to thousands of young black men and women because of his persuasive communicative skills. Moreover, he claims that Mr. Elijah Muhammad trusted his efforts and moved him between different temples across the country to get them "organized" ( $p$. 219). In addition, Malcolm (1992) expresses his excitement about the fact that millions of people worldwide were beyond radio and television were listening to and watching him (p. 205).

These speeches expose the historical and contemporary devaluations of black people by institutional racism in America. They also address the dreadful cruelty against black people since enslaved Africans brought to America until the rise of institutional violence in the form of police killings of unarmed black men and women. Readers in the twentieth-first century can relate with The Autobiography, and they can get mesmerized by the performance of its narrator while he is delivering his speeches. The narrator portrays black people's suffering in America as a seemingly never-ending tragedy. The police killings of unarmed African Americans, such as Eric Garner, Tamir Rice, Michael Brown, and many more, in recent years affirm such tragedies as realities that happen over and over again.

\section{REFERENCES}

Boles, J. (1998). Masters and Slaves in the House of the Lord: Race and Religion in the American South 1740-1870. Lexington: University of Kentucky.

Clark, D. \& Robert R. (2008). Readings in Christian Ethics: Issues and Applications. Grand Rapids, MI: Baker Publication.

Du Bois, W. (1994). The Souls of Black Folk. New York: Dover Thrift.

Franklin, V. P. (1998). African Americans and Jews in the Twentieth Century: Studies in Convergence and Conflict. Kansas City: University of Missouri Press.

Gallagher, C. \& Cameron L. (2014). Race and Racism in the United States. An Encyclopedia of $t h e$ American Mosaic. Vol. 1. Santa Barbra: Greenwood, 2014.

Marable, M. (2011). Malcolm X: A Life of Reinvention. London: Penguin.

Martin, J. R. (2000). Beyond exchange: appraisal systems in English. In S. Hunston \& G. Thompson (Eds.), Evaluation in Text: Authorial Stance and the Construction of Discourse: 
Authorial Stance and the Construction of Discourse (pp. 142-175). Oxford: Oxford University Press, UK.

Martin, J. R. \& David R. (2003). Working with Discourse: Meaning beyond the Clause. London: Continuum.

Martin, J. R. \& P. R. R. White (2005). The Language of Evaluation: Appraisal in English. Basingstoke: Palgrave Macmillan.

Rodriguez, J. (2007). Slavery in the United States: A Social, Political, and Historical Encyclopedia. Santa Barbara, CA: ABC-CLIO.

Rucker, W. \& James U. (2015). Encyclopedia of American Race Riots. Westport: Greenwood.
Strauss, S., \& Feiz, P. (2013). Discourse Analysis: Putting Our Worlds into Words. London, England: Routledge.

Stubbs, M. (1986). A Matter of Prolonged Field Work': Notes Towards a Modal Grammar of English. Applied Linguistics, 7(1), 1-25.

Webster, J. (2015). The Bloomsbury Companion to M. A. K. Halliday. London: Bloomsbury.

White, P. (2011). Appraisal. In J. Zienkowski, J. Östman, \& J. Verschueren (Eds.), Discursive Pragmatics. Amsterdam, Netherlands: John Benjamins Publishing.

X, M. \& Haley, A. (1992). The Autobiography of Malcolm $X$. New York, NY: Ballantine Books. 